\title{
INFLUENCE OF RIBAVIRIN ON PRUNUS DOMESTICA L. REGENERATION, GENOME STABILITY AND VIRUS ERADICATION IN VITRO
}

\author{
Ingrida Mazeikiene ${ }^{1, \#}$, Darius Kviklys ${ }^{1}$, Jurate Brone Siksnianiene ${ }^{1}$, Dainius Zinkus ${ }^{2}$, \\ and Vidmantas Stanys ${ }^{2}$
}

\footnotetext{
${ }^{1}$ Institute of Horticulture, Lithuanian Research Centre for Agriculture and Forestry, Kauno 30, Babtai, 554333 Kaunas distr., LITHUANIA

2 Aleksandras Stulginskis University, Studentų 11, 53361 Kaunas distr., LITHUANIA

\# Corresponding author, i.mazeikiene@Isdi.It
}

Communicated by Edìte Kaufmane

\begin{abstract}
Prunus necrotic ring spot ilarvirus (PNRSV) and Apple chlorotic leaf spot trichovirus (ACLSV) are common in plum orchards. The aim of the study was to obtain virus-free planting material of Prunus domestica $L$. by chemotherapy in vitro. Ribavirin at concentrations of 10 to $50 \mathrm{mg} \cdot \Gamma^{-1}$ was added to Murashige-Skoog (MS) nutrition medium for virus eradication from microshoots. After a two-week period of chemotherapy, meristems were subcultured monthly on MS medium and proliferation index of shoots was estimated. Microshoots were retested by reverse transcription polymerase chain reaction for presence of virus. At lowest concentrations of $10 \mathrm{mg} \cdot \mathrm{I}^{-1}$ ribavirin was entirely ineffective for ACLSV and 10 to $30 \mathrm{mg} \cdot .^{-1}$ was ineffective for PNRSV elimination. Ribavirin concentrations of 40 and $50 \mathrm{mg} \cdot \Gamma^{-1}$ destroyed both pathogens. However, at higher concentrations of 40 and $50 \mathrm{mg} \cdot \mathrm{I}^{-1}$ ribavirin exhibited some signs of phytotoxicity on microshoots in the first subcultivation period. In order to test the genetic stability of the microplants after chemotherapy the amplified fragment length polymorphism (AFLP) method was applied. Plant genome stability in 'Magna Glauca' at concentrations of $40 \mathrm{mg} \cdot \Gamma^{-1}$ was damaged, as the presence of polymorphic AFLP markers were observed.
\end{abstract}

Key words: ACLSV, chemotherapy, PNRSV, virus free plant.

\section{INTRODUCTION}

Vegetative propagation of plums, climate change and the increasing pest population (viral disease vectors) will facilitate the spread of the virus in orchards (Whitfield et al., 2015). However, there are no effective protective measures against viral diseases, which could allow plums to grow normally and develop for a long time in the garden if intensive control of fungal diseases and pests is not undertaken. Common virus infections in Prunus spp. include PNRSV (Prunus necrotic ringspot virus), ACLSV (Apple chlorotic leafspot virus), PPV (Plum pox virus) and PDV (Prune dwarf virus) (Nemeth, 1986; Cieszlinska and Malinowski, 2002; Cieszlinska and Morgas, 2010). PNRSV and ACLSV are common virus diseases in plum trees in the genetic resource orchard in the Horticulture Institute of the Lithuanian Research Centre for Agriculture and Forestry (LAMMC) (16.8\% and 4.8\%, respectively). Low infection rates $(1.6 \%)$ of mixed infections involving PNRSV and
$A C L S V$ were investigated in plum trees. Trees damaged by mixed infections were asymptomatic (Mažeikienè et al., 2016).

PNRSV belongs to the Bromoviridae family, Ilarvirus genus (Paduch-Cichal et al., 2011) and infect the plants of Prunus and Rosa genus: plums, cherries, peaches, apricots, and almonds (Moury et al., 2001). Virus vectors are mites, nematodes and trips (Smith et al., 1988; Scott, 2014). The virus can also spread through infected pollen and seeds (Scott, 2014). Virus-induced damage is significant for plum harvests (Nemeth,1986; Cieszlinska and Malinowski, 2002). PNRSV can reduce bud counts in nurseries, reduce fruit growth (10 to $30 \%$ ), fruit yield (20 to $60 \%$ ), delay fruit maturity and increase winter injury susceptibility in orchards (Saunier, 1972).

ACLSV belongs to the Flexiviridae family and Trichovirus genus (Martelli et al., 1994) and infects most plants of the 
Rosaceae family. It is more commonly found in pome fruits like apple and pear (Pupola et al. 2011; Mazeikiene et al. 2018) and less often in stone fruits — cherries, plums, apricots, peaches (Nemeth, 1986; Ulubas et al., 2004; Niu et al., 2012; Gospodaryk et al., 2013). ACLSV is easily spread through grafting and mechanical inoculation; there are no biological vectors. $A C L S V$ is latent in most cultivars of plums (infected trees do not manifest observable symptoms). ACLSV is often detected in co-infections and can have a devastating effect on plum tree growth and productivity (Nemeth, 1986).

Scientists have been investigating the possibility of removing virus from plant material for several decades. The positive result depends on the culture of the plant, structural and biological characteristics of the virus, the interaction among the virus and the host plant and the chosen method of virus contamination. Virus eradication by thermotherapy and grafting at the tip of the shoots is limited in stone fruits, due to low percentage of plant survival (Deogratias et al., 1989). Chemotherapy in vitro for obtaining PPV-free plants was investigated by Paunovic with colleagues (2007). Eradication of some viral pathogens from herbaceous and woody plants by chemotherapy method has been successfuly used (Pūpola et al., 2009; Panattoni et al., 2013; Hu et al., 2015; Singh, 2015). Chemical antiviral agents are being used to obtain virus free plants. The antivirus agent ribavirin (Virasol) 1- $\beta$-ribofuranosyl-1,2,4,-triazole-3-carboxamide is guanosine (ribonucleic) analogue that is used to stop viral RNA synthesis and viral mRNA capping. Ribavirn's antiviral effect is by inducing hyper mutations in RNA viruses, which is lethal for virus replication (Crotty et al., 2001; Graci et al., 2005).

Manipulation in vitro leads to genetic instability of plants. Genome mutations were observed in different plants in vitro (Hashmi et al., 1997; Zucchi et al., 2002; Ngezahayo et al., 2006; Tiwari et al., 2013). The amplified fragment length polymorphism (AFLP) presents the most suitable and established method for plant genome investigation. AFLP markers have the potential to resolve genetic differences of DNA fingerprints (Ulrich et al., 1999). AFLP studies have shown an insufficient genetic stability in some plant populations using AFLP (Wen et al. 2005; Tiwari et al. 2013).

The aim of this study was to identify the most effective way of eliminating ACLSV and PNRSV pathogens from $P$. domestica shoots using chemotherapy and in vitro methods to obtain virus-free and genetically stable planting material.

\section{MATERIAL AND METHODS}

Plant material and nutrition medium in vitro. $P$. domestica cultivars that were maintained in the fields of the Institute of Horticulture LAMMC formed the source plant material for breeding and propagation. 'Magna Glauca' and 'Cacanska Rana' shoots with mixed infection (PNRSV and $A C L S V$ ) were chosen for chemotherapy. The nodal explants were sterilised with $0.2 \%$ solution of Chapion WP and Gra- nozan (mix solution) for 15 minutes, rinsed twice with sterile water, immersed in $0.1 \%$ solution of $\mathrm{HgCl}_{2}$ for 7 minutes, and rinsed twice with sterile distillate water. After sterilisation the nodal explants were inoculated on $\mathrm{Mu}$ rashige-Skoog (MS) (Murashige and Skoog, 1962) medium (pH 5.8) supplemented with $0.75 \mathrm{mg} \cdot \mathrm{l}^{-1}$ 6-Benzylaminopurine (BAP) and $014 \mathrm{mg} \cdot \mathrm{l}^{-1}$ Indole-3-butyric acid (IBA) in combination with sucrose at $30 \mathrm{~g} \cdot \mathrm{l}^{-1}$ and phytoagar $7 \mathrm{~g} \cdot \mathrm{l}^{-1}$ and were maintained in cultivation room at $21 \pm 2{ }^{\circ} \mathrm{C}$ and photoperiod 16-h under cool white fluorescent light (50 $\mu \mathrm{mol} \mathrm{m} \mathrm{s}^{-1}$ PPFD).

Chemotherapy for virus eradication. Multiplied cultures (PNRSV and ACLSV infected plums shoots $0.8 \pm 0.2 \mathrm{~cm}$ ) were treated on MS medium with ribavirin for two weeks. Five different concentrations of ribavirin were used: 10, 20, 30,40 , and $50 \mathrm{mgl}^{-1}$. Shoots were maintained in the cultivation room at $21 \pm 2{ }^{\circ} \mathrm{C}$ and photoperiod 16-h under cool white fluorescent light $\left(50 \mu \mathrm{mol} \mathrm{m} \mathrm{s}^{-1}\right.$ PPFD). After chemotherapy treatment, meristems $(0.2 \mathrm{~cm})$ were subcultivated monthly on MS medium. The shoot proliferation index was evaluated after 4 and 8 weeks.

PCR for virus detection. Shoots $0.8 \pm 0.2 \mathrm{~cm}$ in length were retested by polymerase chain reaction (PCR) method for virus detection after eight weeks (two subcultivatios). The total RNA was extracted from fresh tissues of microshoots using the GeneJET Plant RNA Purification Mini Kit (Thermo Scientific Ltd.) according to the supplied protocol. The RevertAid First Strand cDNA Synthesis Kit (Thermo Scientific Ltd.) was used for the synthesis of the complementary DNA strand (cDNA) according to the manufacturer's protocol. Oligonucleotide primer pairs PNRSVf 5'GAACCTCCTTCCGATTTAG3' / PNRSVr 5'GCTTCCCTAACGGGGCATCCAC3' by SánchezNavarro et al. (2005) and ACLSVf 5'TTCATGGAAAGACAGGGGCAA3' / ACLSVr

5'AAGTCTACAGGCTATTTATTATAAGTCTAA3' by Menzel et al. (2002) were used for amplification of virus coat protein (CP) gene fragments $346 \mathrm{bp}$ and $667 \mathrm{bp}$, respectively. The amplification reaction $(20 \mu \mathrm{l})$ was composed of $10 \times$ Taq DNA polymerase buffer $2.5 \mu \mathrm{l}, 2.5 \mathrm{mM}$ $\mathrm{MgCl} 22 \mu \mathrm{l}, 0.2 \mathrm{mM}$ dNTP mix $2 \mu \mathrm{l}, 0.1 \mu \mathrm{M}$ forward and reverse primer $0.2 \mu \mathrm{l}, 0.1$ units Taq DNA polymerase and $200 \mathrm{ng}$ of cDNA. The amplification reaction was performed in a Master-cycler gradient $\mathrm{S}$ thermal cycler (Eppendorf Ltd.) under the following conditions: $5 \mathrm{~min}$ at $95^{\circ} \mathrm{C}, 35 \mathrm{cy}-$ cles of $30 \mathrm{~s}$ at $95{ }^{\circ} \mathrm{C}, 40 \mathrm{~s}$ at $59{ }^{\circ} \mathrm{C}$ (for PNRSV) and $61{ }^{\circ} \mathrm{C}$ (for ACLSV), $40 \mathrm{~s}$ at $72{ }^{\circ} \mathrm{C}$ and the final elongation step of $10 \mathrm{~min}$ at $72{ }^{\circ} \mathrm{C}$. The amplification products were analysed in $1.5 \%(\mathrm{w} / \mathrm{v})$ agarose gel using electrophoresis.

AFLP for genome stability. Genomic DNA was extracted from $0.1 \mathrm{mg}$ fresh leaf tissue of microshoots using the CTAB-based extraction protocol by Doyle and Doyle (1990). The amplified fragment length polymorphism (AFLP) method was applied for genetic stability testing of the plum shoots obtained after chemotherapy in vitro. AFLP analysis was performed according to the Vos et al. (1995) 
method. The AFLP Plant Fingerprinting Kit (Applied Biosystems Ltd.) was used for sample preparation. All procedures were performed according to manufacturer protocol. About $150 \mathrm{ng}$ of genomic DNA was digested with restriction endonucleases EcoRI and TruII (MseI) (Thermo Scientific Ltd.) and corresponding adaptors were ligated. Preamplification was carried out with standard primers EcoRI A and MseI C (205 $\mathrm{nM}$ each) in a $20 \mu \mathrm{l}$ reaction volume containing $4 \mu \mathrm{l}$ of diluted restriction-ligation mix and $15 \mu \mathrm{l}$ of AFLP Amplification Core Mix (Applied Biosystems Ltd.). Pre-amplification conditions were as follows: $94{ }^{\circ} \mathrm{C}$ for 2 min followed by 20 cycles of $20 \mathrm{~s}$ at $94{ }^{\circ} \mathrm{C}, 30 \mathrm{~s}$ at $56{ }^{\circ} \mathrm{C}$ and $120 \mathrm{~s}$ at $72{ }^{\circ} \mathrm{C}$, followed by a final step of 2 min at $72{ }^{\circ} \mathrm{C}$ and $30 \mathrm{~min}$ at $60^{\circ} \mathrm{C}$. Selective PCR amplification was carried out under the same reaction conditions, except that $2 \mu \mathrm{l}$ of diluted pre-amplification template was used and MseI/EcoRI primers sets (CG/ACC, CTC/ACC, CAA/ACC, CTA/ACC, CG/ACT, CTC/ACT, CAA/ACT, CTA/ACT) were used at $50 \mathrm{nM}$ and $250 \mathrm{nM}$ concentration, respectively. Selective amplification was performed using the following programme: an initial cycle of $30 \mathrm{~s}$ at $94{ }^{\circ} \mathrm{C}$, $30 \mathrm{~s}$ at $65^{\circ} \mathrm{C}$ and $80 \mathrm{~s}$ at $72{ }^{\circ} \mathrm{C}$, followed by 10 cycles of 30 $\mathrm{s}$ at $94{ }^{\circ} \mathrm{C} 30 \mathrm{~s}$ at 65 to $56{ }^{\circ} \mathrm{C}, 1^{\circ} \mathrm{C}$ per cycle, $80 \mathrm{~s}$ at $72{ }^{\circ} \mathrm{C}$; followed by 23 cycles of $30 \mathrm{~s}$ at $94{ }^{\circ} \mathrm{C}, 30 \mathrm{~s}$ at $55^{\circ} \mathrm{C}$ and 80 s at $72{ }^{\circ} \mathrm{C}$, and a final step of $5 \mathrm{~min}$ at $72{ }^{\circ} \mathrm{C}$. Samples were prepared for capillary electrophoresis by mixing $1 \mu$ of the PCR product with $8.88 \mu \mathrm{l}$ of highly deionised (Hi-Di) formamide and $0.12 \mu \mathrm{l}$ of Gene Scan 500 LIZ ladder (Ap- plied Biosystems, Ltd.), and analysed using the Genetic Analyzer 3130 (Applied Biosystems Ltd.).

Statistical analysis. The data of the experiment were analysed by ANOVA. The treatment effects were tested by the least significant differences $\mathrm{LSD}_{05}$ and $p$ tests by SigmaStat software.

\section{RESULTS}

Co-infection in shoots of 'Magna Glauca' and 'Cacanska Rana' was confirmed by PCR. Conditions for micropropagation of plums shoots in vitro were investigated in our laboratory in previous studies. After establishment of aseptic culture and multiplication of shoots (Fig. 1), mixed infections of PNRSV and ACLSV in shoots were re-confirmed by PCR (positive control in Fig. 3).

The multiplication index before chemotherapy in vitro is labelled as Control R_0 in Figure 2. 4.6 to 6.3 microshoots of 'Magna Glauca' and 4.1 to 4.3 of 'Cacanska Rana' developed per initial individual during propagation. The multiplication indexes of plum shoots differed after ribavin treatments (Fig. 2). The antivirus agent had a significant phytotoxic effect on shoot proliferation of 'Magna Glauca' and 'Cacanska Rana' in the first subcultivation period (four weeks after chemotherapy). The lowest proliferation was observed for variant R_40 for both cultivars — multiolica-
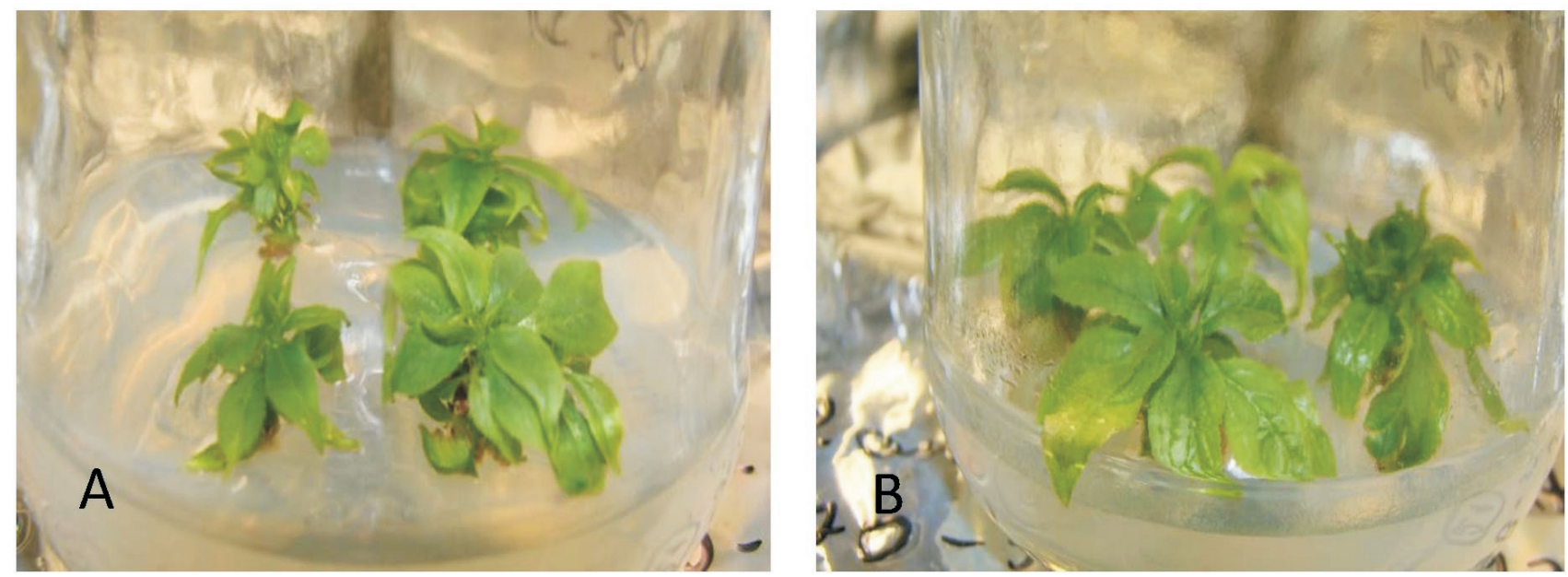

Fig. 1. 'Magna Glauca' (A) and 'Cacanska Rana' (B) shoots with mixed infection (PNRSV and ACLSV) were multiplied on modified MS medium.

$\square 4$ weeks ( $\operatorname{LSD} .05=0.72) \quad \square$ weeks $($ LSD $.05=2.12)$

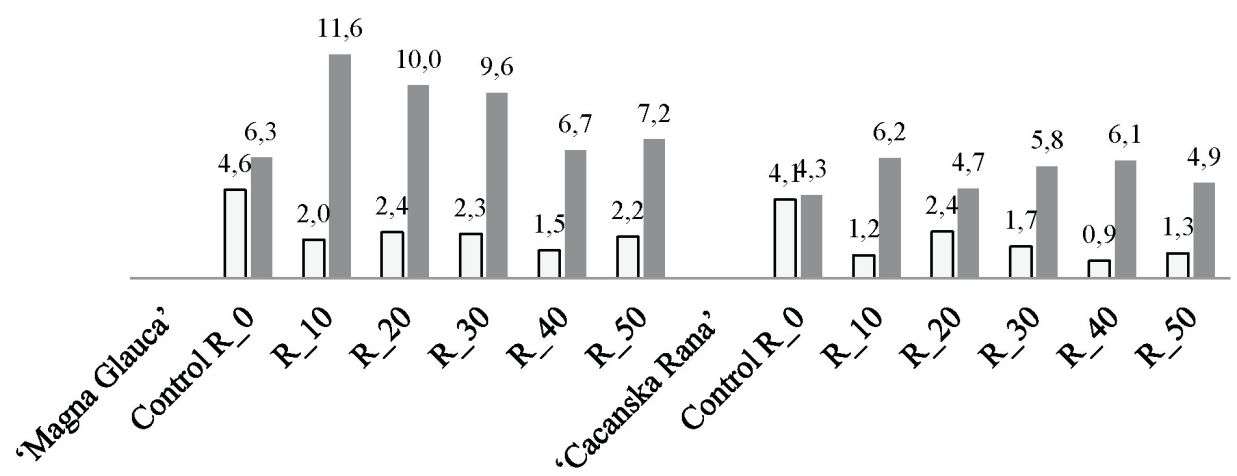

Fig. 2. Plum shoots multiplication index after chemotherapy with ribavirin. 


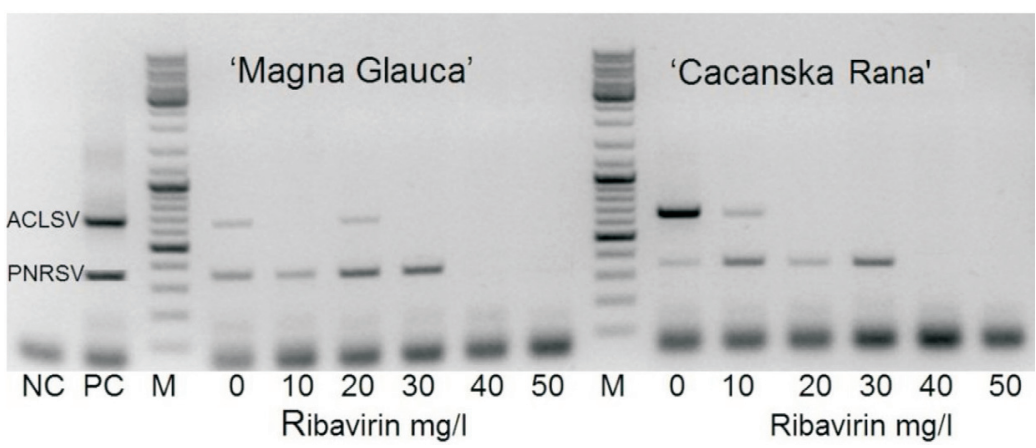

Fig. 3. Virus infection in plum shoots after chemotherapy with ribavirin. The molecular weight of PCR products was estimated by comparison with 1 kb DNA ladder SM1173 (Thermo Scientific Ltd.); NC, negative control, DNA of plum tree with virus free certificate; PC, positive control, DNA of shoots in vitro before chemotherapy. tion index 1.5 for 'Magna Glauca' and 0.9 for 'Cacanska Rana'. Ribavirin had a positive effect at the lowest concentrations $\left(10,20\right.$, and $\left.30 \mathrm{mg} \cdot \mathrm{l}^{-1}\right)$ on 'Magna Glauca' shoot proliferation in the second subcultivation period (eight weeks after chemotherapy); the microshoot proliferation index significantly increased from 6.3 (Contol $\mathrm{R} \_0$ variant) to $11.6,10.0$, or 9.6 after ribavirin treatments $\left(\mathrm{R} \_10, \mathrm{R} \_20\right.$, or R_30).

Presence of the viral infection in microshoots was retested by PCR eight weeks after chemotherapy. Specific virus RNA fragments were identified in agarose gel (Fig. 3). The lowest concentrations of ribavirin (10 to $\left.20 \mathrm{mg} \cdot \mathrm{l}^{-1}\right)$ were entirely ineffective for $A C L S V$ elimination and concentrations from 10 to $30 \mathrm{mg} \mathrm{l}^{-1}$ were inefficient for PNRSV elimination. The highest ribavirin concentrations of 40 and 50 $\mathrm{mg} \cdot \mathrm{l}^{-1}$ were caused loss of both viral pathogens. Elimination of the virus was confirmed in all microshoots of cultivars 'Magna Glauca' and 'Cacanska Rana'.

Genome mutations in plant material before and after manipulation in vitro were observed by AFLP method in our study. Eight combinations of primers revealed molecular markers that generated DNA fingerprints with 1075 and 1110 fragments for each cultivar (Table 1). The AFLP assays generated 117 to 152 DNA fragments per primer combination. Polymorphic fragments in DNA fingerprints of cultivars with primer pairs CG/ACC and CTC/ACC were not detected. The highest number of polymorphic DNA fragments (16) was detected with primer pair CG/ACT. The analysis of AFLP showed that the genomes of the plum cultivars 'Magna Glauca' and 'Cacanska Rana' are very similar and are mostly stable for manipulation in vitro. The fragments generated by eight primer pairs were confirmed to be monomorphic across tested cultivars after chemotherapy with $10,20,30$, and $50 \mathrm{mg} \cdot \mathrm{l}^{-1}$ of ribavirin. Plant genome stability in cultivar 'Magna Glauca' was damaged after 40 $\mathrm{mg} \cdot \mathrm{l}^{-1}$ ribavirin treatment. Instability of the genome was detected with primer pair CG/ACC. Five DNA fragments (56 bp, 76 bp, 131 bp, 161 bp, 245 bp) were newly presented, and absence of two monomorphic markers (134 bp, $150 \mathrm{bp}$ ) were found in the DNA fingerprint.

\section{DISCUSSION}

Chemotherapy has been successful in removing viruses from several plant species where thermotherapy is applicable (Panattoni et al., 2013). Also, the combination of thermotherapy with chemotherapy has been successful (Verma et al., 2005; Hu et al., 2005). Ribavirin, synthesised by Sidwell et al. (1972), was tested as an antiviral agent in plant chemotherapy, and showed significant therapeutic potential against plant viruses. However, other synthetic chemical compounds have also been investigated (Verma et al., 2005; Xia et al., 2006; Zhao et al., 2006). Ribavirin was previously tested for ability to eliminate viruses from more than nine families of viruses, using various herbaceous and woody plants (Panattoni et al., 2013). It was found that high concentration of ribavirin is required for virus eradication, but that effects are devastating for the herbaceous plant material. Zhang et al. (2006) reported that strawberry mottle virus and strawberry mild yellow edge virus are not sensitive to ribavirin and were not eliminated from strawberry plants. Chemotherapy with ribavirin on sugarcane was also unsuccessful due to the sensitivity of the explants to the antivirus agent (Permesur and Saumtally, 2001). High ribavirin concentrations (30 mg. $1^{-1}$ and higher) were found to cause meristem necrosis in potato shoots (Danci et al., 2009). We were able to eradicate the mixed infections of $A C L S V$ and PNRSV from plum shoots in vitro using chemotherapy with ribavirin (Fig. 3). We did not use more than 50 $\mathrm{mg} \cdot \mathrm{l}^{-1}$ concentrations of ribavirin, as Paunovic et al. (2007) found that chemotherapy with high concentrations was lethal to plum shoots of cultivar 'Cacanska Lepotica'. In our study, infected shoots of 'Magna Glauca' and 'Cacanska Rana' multiplied well on modified MS nutrition medium, and did not show signs of viral infection (Fig. 1). ACLSV was more sensitive to ribavirin than $P N R S V$. A concentration of $20 \mathrm{mg} \cdot \mathrm{l}^{-1}$ ribavirin in the MS nutrition medium had lethal effects on the ACLSV pathogen in plum shoots. According to other researchers (Deogratias et al., 1989; Hansen and Lane, 1985), the removal of ACLSV from apple shoots can be achieved with a lower concentration (up to 20 $\mathrm{mg} \cdot \mathrm{l}^{-1}$ ) of antiviral agent than from stone fruit shoots (40-100 mg. $\left.1^{-1}\right)$. In our study, ribavirin concentration of 40 $\mathrm{mg} \cdot \mathrm{l}^{-1}$ was optimal for the eradication of PNRSV from plum shoots. Ribavirin concentration of $40-60 \mathrm{mg} \cdot \mathrm{l}^{-1}$ is also suitable for PPV elimination from plum shoots (Paunovic et al., 2007). We noticed that during the first period of subculture, all tested concentrations of ribavirin had a negative impact on plum shoot development. However, positive effects on shoots induction in vitro for 'Magna Glauca' and 'Cacanska Rana' were observed in the second sub-cultivation period (eight weeks after chemotherapy). The multiplication index was significantly higher in variants where ribavirin was 
used at lower concentrations (10-30 mg. $\mathrm{l}^{-1}$ ) (Fig. 2). Our previous work showed that $20 \mathrm{mg} \cdot \mathrm{l}^{-1}$ exposure of apple shoots 'Antonovka' in vitro to ribavirin had positive effects on the proliferation index (data not published). A high multiplication index is an important indicator for production of planting material. The multiplication index of 'Cacanska Rana' (6.1 and 4.9) and 'Magna Glauca' (6.7 and 7.2) obtained in virus-free variants R_40 and R_50 were relatively high (Fig. 2).

Based on published reports on occurrence of somaclonal variation (Zucchi et al., 2002; Wen et al., 2005; Ngezahayo et al., 2006) among plants grown through enhanced axillary branching cultures, we estimated genetic stability of plum shoots before and after manipulations in vitro. AFLP analysis showed that genome instability in vitro can be detected in $P$. domestica cultivars (Table 1). AFLP is a sensitive method for testing for instability of the plant genome, especially when various primer pairs are used for selective amplification (Beismann et al., 1997; Ulrich et al., 1999). Using eight pairs of primers, we obtained only monomorphic DNA fragments with seven primer pairs in the plum shoots before and after chemotherapy. Polymorphic DNA fragments were obtained with the primer combination MseI/EcoRI - CG/ACC (3.9\%) in the genome of 'Magna Glauca'. A total of 1075 genetic makers were found and $0.5 \%$ of them showed genetic instability. That is not a high genomic polymorphism, but attention should be paid to somaclonal variation in vitro of individual plum cultivars. Somaclonal variation was also found at different levels in Secale sereale - $8.8 \%$ (de la Puente et al., 2008), and Echinacea purpurea - from 1.6\% to 20.6\% (Chuang et al., 2009). We did not find polymorphic AFLP markers in the 'Cacanska Rana' shoot's genome in vitro. A positive aspect is that somaclonal variation provides an alternative tool for

Table 1

GENETIC STABILITY OF PLUM SHOOTS BEFORE AND AFTER CHEMOTHERAPY IN VITRO

\begin{tabular}{|c|c|c|c|}
\hline \multirow[t]{2}{*}{$\begin{array}{l}\text { Primer pair } \\
\text { MseI/EcoRI }\end{array}$} & \multicolumn{3}{|c|}{$\begin{array}{c}\text { AFLP fragments detected in DNA of initial plant material } \\
\text { and in DNA of shoots after chemotherapy and } \\
\text { multiplication in vitro }\end{array}$} \\
\hline & $\begin{array}{l}\text { 'Cacanska } \\
\text { Rana' } \\
\text { initial/in vitro }\end{array}$ & $\begin{array}{c}\text { 'Magna Glauca' } \\
\text { initial/in vitro }\end{array}$ & $\begin{array}{c}\text { Polymorphic AFLP } \\
\text { markers }\end{array}$ \\
\hline CG/ACC & $127 / 127$ & $127 / 130 *$ & $\begin{array}{l}\text { *In treatment R_40 } \\
\text { Presence of new frag- } \\
\text { ments - } 56 \mathrm{bp} ; 76 \mathrm{bp} ; \\
131 \mathrm{bp} ; 161 \mathrm{bp} ; 245 \mathrm{bp} ; \\
\text { Absence fragments - } \\
134 \mathrm{bp} ; 150 \mathrm{bp}\end{array}$ \\
\hline CTC/ACC & $142 / 142$ & $142 / 142$ & \\
\hline CAA/ACC & $145 / 145$ & $143 / 143$ & \\
\hline CTA/ACC & $122 / 122$ & $117 / 117$ & \\
\hline CG/ACT & $152 / 152$ & $136 / 136$ & \\
\hline CTC/ACT & $143 / 143$ & $138 / 138$ & \\
\hline CAA/ACT & $135 / 135$ & $137 / 137$ & \\
\hline CTA/ACT & $144 / 144$ & $135 / 135$ & \\
\hline Total: & $1110 / 1110$ & $1075 / 1078$ & \\
\hline
\end{tabular}

breeders to obtain genetic variability in horticultural crops (Krishna et al., 2016). Further research in vivo for the evaluation of equability of the $P$. domestica propagation material after virus eradication and micropopogation is required.

\section{CONCLUSIONS}

Chemotherapy in vitro with ribavirin concentration at $40 \mathrm{mg} \cdot \mathrm{l}^{-1}$ is optimal to eradicate viruses PNRSV (Ilarvirus genus) and ACLSV (Trichovirus genus) from plum shoots. The toxic effects of ribavirin on development and growth of plum shoots disappears one month after chemotherapy. Chemotherapy with ribavirin at concentrations $10-30 \mathrm{mg} \cdot 1^{-1}$ has a positive effect on the proliferation index of shoots 'Magna Galauca' and 'Cacanska Rana' in vitro. An AFLP analysis of genetic stability after virus eradication in vitro is required for plants of $P$. domestica.

\section{REFERENCES}

Beismann, H., Barker, J. H. A., Karp, A. Speck, T. (1997). AFLP analysis sheds light on distribution of two Salix species and their hybrid along a natural gradient. J. Mol. Ecol., 6 (10), 989-993.

Chuang, S. J., Chen, C.L., Chen, J. J., Chou, W. Y., Sung, J. M. (2009). Detection of somaclonal variation in micro-propagated Echinacea purpurea using AFLP marker. Sci. Hortic., 120 (1), 121-126.

Cieślińska, M., Morgaś, H. (2010). Occurrence and detection of lesser known viruses and phytoplasmas in stone fruit orchards in Poland. Folia Horticult. Ann., 22 (2), 51-57.

Cieszlinka, M., Malinowski, T. (2002). Virus and virus-like diseases of fruit tree and small fruit. Zeszyty Naukowe Instytuta Sadownictwa i Kwiaciarstwa Skierniewicach, 10, 197-206.

Crotty, S., Maag, D., Cameron, C. E., Andino, R. (2001). RNA virus error catastrophe: Direct molecular test by using ribavirin. J. Proc. Natl. Acad. Sci. USA, 12, 6895-6900.

Danci, O., Erdei, L., Vidacs, L., Danci, M., Baciu, A., David, I., Berbentea, F. (2009). Influence of ribavirin on potato plants regeneration and virus eradication. J. Horticult. For. Biotechnol., 13, 421-425.

De la Puente, R., González A. I., Ruiz M. L., Polanco C. (2008). Somaclonal variation in rye (Secale cereale L.) analyzed using polymorphic and sequenced AFLP markers. In Vitro Cell. Dev. Biol. Plant, 44 (5), 419-426.

Deogratias, J. M., Dosba, F., Lutz, A. (1989). Eradication of prune dwarf virus, prunus necrotic ringspot virus, and apple chlorotic leaf spot virus in sweet cherries by a combination of chemotherapy, thermotherapy, and in vitro culture. Can. J. Plant Pathol., 11, 337-342.

Doyle, J. J., Doyle, J. L. (1990). A rapid total DNA preparation procedure for fresh plant tissue. Focus, 12, 13-15.

Gospodaryk, A., Moročko-Bičevska, I., Pūpola N., Kāle, A. (2013). Occurrence of stone fruit viruses in plum orchards in Latvia. Proc. Latvian Acad. Sci., Section B, 67 (2), 116-123.

Graci, J. D., Cameron, C. E. (2005). Mechanisms of action of ribavirin against distinct viruses. Rev. Med. Virol., 16 (1), 37-48.

Hansen, A. J., Lane, D. W. (1985). Elimination of Apple chlorotic leafspot virus from apple shoot. J. Plant Disease, 69 (2), 134-135.

Hashmi, G., Huetell, R., Meyer, R., Krusberg, L., Hammerschlag, F. (1997). RAPD analysis of somaclonal variations derived from embryo callus cultures of peach. J. Plant Cell Rep., 16, 624-627.

Hu, G., Dong, Y., Zhang, Z., Fan, X., Ren, F., Zhou, J. (2015). Virus elimination from in vitro apple by thermotherapy combined with chemotherapy. $J$. PCTOC., 121 (2), 435-443. 
Krishna, H., Alizadeh, M., Singh, D., Singh, U., Chauhan, N., Eftekhari, M., Sadh, R. K. (2016). Somaclonal variations and their applications in horticultural crops improvement. 3 Biotech., 6 (1), 54.

Martelli, G. P., Candresse, T., Namba, S. (1994). Trichovirus, a new genus of plant viruses. Arch. Virology, 134, 451-455.

Mažeikienè, I., Šikšnianienè, J. B., Stanys, V. (2016). The virological state of plums in the genetic resource orchard and genetic characteristic of Plum pox virus. Sodininkystè ir Daržininkystè, 35 (3-4), 3-15 (in Lithuanian).

Mazeikiene, I., Siksnianiene, J. B., Gelvonauskiene, D., Bendokas, V., Stanys, V. (2018). Prevalence, genetic diversity and molecular variability of Apple Chlorotic Leaf Spot Virus capsid protein in Lithuania. JPDP, 125 (4), 389-396.

Menzel, W., Jelkmann, W., Maiss, E. (2002). Detection of four apple viruses by multiplex RT-PCR assays with coamplification of plant mRNA as internal control. J. Virol. Methods, 99, 81-92.

Moury, B., Cardin, L., Onesto, J. P., Candresse, T., Poupet, A. (2001). Survey of Prunus necrotic ringspot virus in rose and its variability in rose and Prunus spp. J. Phytopathol., 91, 84-91.

Murashige, T., Skoog, F. (1962). A revised medium for rapid growth and bio-assays with tobacco tissue cultures. J. Physiol. Plantarum, 15 (3), 473-479.

Nemeth, M. (1986). Virus. Mycoplazma, and Ricketsia Diseases of Fruit Tree. Academia Kiado, Budapest. 1321 pp.

Ngezahayo, F., Guo, W. L., Gong, L., Li, F. X., Liu, B., Dong, Y. (2006). Genomic variation in micropropagated Robinia ambigua 'idahoensis' revealed by RAPD markers. J. Hort. Sci., 41 (6), 1466-1468.

Niu, F., Pan, S., Wu, Z., Jiang, D., Li, S. (2012). Complete nucleotide sequences of the enomes of two isolates of apple chlorotic leaf spot virus from peach (Prunus persica) in China. J. Arch. Virol., 157, 783-786.

Paduch-Cichal, E., Sala-Rejczak, K. (2011). Biological and molecular characterization of Prunus necrotic ringspot virus isolates from three rose cultivars. J. Acta Physio. Plant., 33 (6), 2349-2354.

Panattoni, A,. Luvisi, A., Triolo, E. (2013) Elimination of viruses in plants: Twenty years of progress. Span. J. Agric. Res., 11 (1), 173-188.

Paunovic, S., Ruzic, D., Vujovic, T., Milenkovic, S., Jevremovic, D. (2007). In vitro production of Plum pox virus-free plums by chemotherapy with ribavirin. J. Biotechnol. Biotechnol. Eq., 21 (4), 417-421.

Permesur, Y., Saumtally, A. (2001). Elimination of sugarcane yellow leaf virus and sugarcane bacilliform virus by tissue culture. (Mauritius): Food and Agricultural Research Council., 127-133.

Pūpola, N., Lepse, L., Kāle, A., Moročko-Bičevska, I. (2009). Occurrence of RBDV in Latvia and virus elimination in vitro by chemotherapy. Sodininkystè ir Daržininkystè, 28 (3), 165-172.

Pūpola, N., Moročko-Bičevska, I., Kāle, A., Zeltinš A. (2011). Occurrence and diversity of pome fruit viruses in apple and pear orchards in Latvia. $J$. Phytopathol., 159, 597-605.
Sánchez-Navarro, J.A., Aparicio, F., Herranz, M. C., Minafra, A., Myrta, A., Palliss, V. (2005). Simultaneous detection and identification of eight stone fruit trees viruses by one-step RT-PCR. Eur. J. Plant Pathol., 111, 77-84.

Saunier, R. (1972). Incidence d'un virus du type ringspot sur la comportment de deux cultivars du pźcher. La Pomologie Francaise, 14, 175-185.

Sidwell, R. W., Huffman, J. H., Share, G. P., Allen, L. B., Witkowski, J. T., Robins, R. K. (1972). Broad spectrum antiviral activity of virazole 1- $\beta$-D-ribofuranosyl-1,2,4-triazole-3-carboxamide. Science, 177, 705-706.

Singh, B. (2015). Effect of antiviral chemicals on in vitro regeneration response and production of PLRV-free plants of potato. J. Crop Sci. Biotechnol., 18 (5), 341-348.

Smith, I. M., Dunez, J., Phillips, D. H., Lelliott R. A., Archer, S. A. (1988). European Handbook of Plant Deseases. Wiley-Blackwell. 598 pp.

Tiwari, J. K., Chandel, P., Gupta, S., Gopal, J., Singh, B. P., Bhardwaj, V. (2013). Analysis of genetic stability of in vitro propagated potato microtubers using DNA markers. J. Physiol. Mol. Biol. Plants, 19 (4), 587-595.

Ulrich, G., Mueller, L., LaReesa Wolfenbarger, L. (1999). AFLP genotyping and fingerprinting. TREE, 14 (10), 389-394.

Ulubas, C., Erunc, F. (2004). Apple chlorotic leaf spot virus (ACLSV) status in Turkey and sensitive detection using advanced techniques. Turk. J. Agric. For., 29 (2005), 251-257.

Verma, N., Ram, R., Zaidi, A. A. (2005). In vitro production of Prunus necrotic ringspot virus-free begonias through chemo-and thermotherapy. Sci. Hortic., 103, 239-247.

Vos, P., Hogers, R., Bleeker, M., Reijans, M., van de Lee, T., Hornes, M., Frijters, A., Pot, J., Peleman, J., Kuiper, M., Zabeaum, M. (1995). AFLP: A new technique for DNA fingerprinting. Nucl. Acids Res., 23, 4407-4414.

Wen, X. P., Deng, X. X. (2005). Micropropagation of chestnut rose (Rosa roxburghii Tratt) and assessment of genetic stability in in vitro plants using RAPD and AFLP markers. J. Hort. Sci. Biotechnol., 80 (1), 54-60.

Whitfield, A. E., Falk, B. W., Rotenberg, D. (2015). Insect vector-mediated transmission of plant viruses. J. Virol., 479-480, 278-289.

Xia, Y., Fan, Z., Yao, J., Liao, Q., Li, W., Qua, F., Peng, L. (2006). Discovery of bitriazolyl compounds as novel antiviral candidates for combating the Tobacco mosaic virus. J. Bioorg. Med. Chem. Lett., 16, 2693-2698.

Zhang, Z. H., Xiao, M., Yang, H. Y., Li, H., Gao, X. Y., Du, G. D. (2006). Evaluation and comparison on methods of virus elimination from the strawberry plants. J. Fruit Sci., 23, 720-723.

Zhao,W. G., Wang, J. G., Li, Z. M., Yang, Z. (2006). Synthesis and antiviral activity against Tobacco mosaic virus and 3DQSAR of $\alpha$-substituted-1,2,3-thiadiazoleacetamides. J. Bioorg. Med. Chem. Lett., 16, $6107-6111$.

Zucchi, M. I., Arizono, H., Morais, V. A., Fungaro, M. H. P., Vieira, M. L. C. (2002). Genetic instability of sugarcane plants derived from meristem cultures. J. Genet. Mol. Biol., 25 (1), 91-95.

Received 28 January 2019

Accepted in the final form 24 March 2019

\section{RIBAVIRĪNA IETEKME UZ PRUNUS DOMESTICA L. REG̣ENERĀCIJU, GENOMA STABILITĀTI UN VĪRUSU ELIMINĀCIJU IN VITRO}

PNRSV (Prunus necrotic ring spot) vīruss un ACLSV (Apple chlorotic leaf spot) vīruss ir bieži sastopami plūmju stādījumos. Pētījuma mērḳis ir iegūt vīrusbrīvu Prunus domestica L. stādmateriālu, pielietojot kīmijterapiju in vitro. Ribavirīns tika pievienots Murashige-Skoog (MS) mikrosāḷu barotnei 10 līdz $50 \mathrm{mg} \cdot \mathrm{l}^{-1}$ koncentrācijā vīrusu eliminācijai no mikrodzinumiem. Pēc divu nedēlu ḳimijterapijas perioda tika grieztas meristēmas un turpināta mikropavairošana uz MS barotnes, nosakot proliferācijas koeficientu. Vīrusu eliminācijas efektivitātes novērtēšanai mikrodzinumi tika testēti, izmantojot reversās transkripcijas polimerāzes k̦ēdes reakciju. Tika konstatēts, ka $A C L S V$ eliminācijai zemākā ribavirīna koncentrācija $10 \mathrm{mg} \cdot 1^{-1}$ bija neefektīva, kā arī $P N R S V$ eliminācija pie koncentrācijas 10 līdz $30 \mathrm{mg} \cdot 1^{-1}$ bija neefektīva. Savukārt pie ribavirīna koncentrācijas 40 un $50 \mathrm{mg} \cdot 1^{-1}$ abi patogēni tika sekmīgi eliminēti. Tomēr pie šīs augstās ribavirīna koncentrācijas bija vērojams fitotoksiskums mikroaugu pirmajā pasāāā. Lai noskaidrotu metodes ietekmi uz mikroaugu ǵenētisko stabilitāti, tika pielietota amplificētu fragmentu garuma polimorfisma (AFLP) metode. Škirnei 'Magna Glauca' pie ribavirīna koncentrācijas 40 mg. $1^{-1}$ tika konstatētas ğenētiskas izmaiņas, jo tika atrasti polimorfi AFLP marķieri. 